\title{
THE EFFECTS OF SPORT SKILLS COURSE PROGRAM ON THE BASIC MOTOR STATUS IN THE STUDENTS AT THE FACULTY OF SECURITY STUDIES
}

Original Scientific Paper

\begin{tabular}{|l|l|l|}
\hline DOI 10.5937/zurbezkrim1902065P & COBISS.RS-ID 8632088 & UDK 355.233.22-057.36:796.9 \\
\hline
\end{tabular}

Darko Paspalj,

Faculty of Security Studies, University of Banja Luka ${ }^{1}$

Milan Gužvica,

Faculty of Security Studies, University of Banja Luka

Lazar Vulin

Faculty of Security Studies, University of Banja Luka

Abstract: Using an experimental method, this study was conducted to determine, whether the program of physical training in the subject of Sports Skills in Security, under regular working conditions, can result in significant changes in the motor skills in the students at the Faculty of Security Studies in Banja Luka. The study was conducted during the 60 -hour course in the 2018/2019 academic year, in a sample of 31 first-year male students aged between 19 and 20 at the Faculty of Security Sciences, with an initial measurement at the beginning and final measurement at the end of the first semester. The sample of variables consisted of seven motor skill tests used in candidate selection for admission to the Faculty of Security Studies. Using the Student's t-test for dependent samples, it was found that programed exercise resulted in statistically significant differences in the status of students' motor skills in the initial and final measurements, with the following variables: number of pushups in 10 seconds (MSKL), stick agility (MOCP), somersault - backward somersault - running (MKNT), and hand tapping (MTAP), thus partially confirming the basic hypothesis. The research findings could be used as a valuable information in the further education of students, that is, to plan and program teaching contents of the subject Special Physical Education.

Keywords: students, sport skills, regular lessons/teaching, motor skills

\section{INTRODUCTION}

The subject of Sport Skills in Security, which was launched by the Faculty of Security Studies in Banja Luka, is aimed at developing and improving

\footnotetext{
1 Corresponding author: dr Darko Paspalj, Assistant Professor, Faculty of Security Studies, University of Banja Luka. E-mail: darko.paspalj@fbn.unibl.org
} 
natural forms of movement which have been noted, through experience and practice, to have not been adopted in the earlier stage of child development, who are now students, to a level that would enabled them to adopt more complex forms of movement faster and more efficiently. Through the improvement of natural forms of movement, based on scientific findings, it is realistic to assume that this new program in the subject Sport Skills in Security, will also affect the development of motor skills and morphological characteristics, which are important for the further education of students or the acquisition of the contents of the subject Special Physical Education. This assumption is based on numerous scientific studies, which claim that the optimum level of motor skills and morphological characteristics contribute not only to faster learning and adoption of complex motor programs in Special Physical Education, but also to the possibility of their practical application in real life situations: (Milošević, 1985; Božić, Milošević and Zulić, 1990; Milošević et al.,1994; Blagojević et al., 1994; Mudrić, Jovanović, Milošević and Ćirković, 1994; Stojičić, 1994; Blagojević, 1996, 1997; Dopsaj, Milošević, Arlov, Blagojević and Stefanović, 1996; Milošević, Mudrić and Amanović, 2003; Dopsaj, Milošević, Blagojević and Mudrić; 2002; Amanović, Mudrić and Jovanović, 2002; Subotički; 2003; Amanović, Milošević and Mudrić, 2004; Gužvica, 2005; 2006; 2007; 2008; Paspalj, 2008; 2009; 2010; 2012; 2013; Janković, Vučković and Blagojević, 2014).

Thus, the Sport Skills in Security course is delivered as a part of the study program at the Faculty of Security Studies, which is an optional course aimed at developing morphological characteristics, motor and functional skills as well as other knowledge necessary for a successful performance of security jobs. This 15-week course, or a total of 60 teaching hours, is scheduled 4 times per week in the first year of studies. The objective of the course is to enable the students at the Faculty of Security Studies to develop and acquire motor skills important for successful learning, mastering and performing activities characteristic of prospect security personnel. Additionally, the aim is to familiarize the students with the ways of dealing with simple and complex situations and obstacles occurring under the spatially and temporally predictable conditions, as well as to improve their health, based on contemporary scientific, theoretical and practical knowledge.

The expected outcome of the course is that the students fully adopt biotic movements, develop motor and functional skills, improve morphological characteristics which will positively influence the easier mastering of specific knowledge and skills typical of performing complex motor problems that prospect security workers may encounter in their professional work. Through teaching contents, the students perform physical activities aimed at developing endurance, force, speed, coordination, flexibility, agility, reactivity and balance, while special attention is paid to the development of knowledge in order to overcome horizontal and vertical obstacles in laboratory and real conditions, as well as mastering deep and calm water surfaces by swimming and diving, and rescuing drowning persons in shallow and deep waters.

64 Of the 60 classes envisaged, 15 classes are held at the City Olympic Pool through the development of certain skills for mastering deep and calm surfaces by swimming and scuba-diving (aimed developing agility and feeling in space), while 30 classes are realized in the Athletic hangar at the Faculty of Physical Education and Sports, University of Banja Luka, with the aim of improving the 
status of motor skills, primarily coordination, force and strength, speed, endurance, flexibility, agility, reactivity and balance.

The program encompasses those kinesiological activities that are represented in the regular program. These are natural forms of movement with specific tasks and different forms of movement, and a set of body-sculpting exercises - individually and in pairs. The training process for the development of basic motor skills was realized through exercises using an individual's own bodyweight and training paraphernalia, whereby circuit training and stations were used, as well as the obstacle course. Overcoming obstacles was performed through natural forms of movement, meaning that the students had to overcome a number of obstacles indoors without stopping in the shortest possible time. In the implementation of the aforementioned contents, simple and then complex methodological and organizational forms of work were applied first. Tests and measurements were not encompassed by the program but were performed prior to and after the application of the program.

\section{The subject and aim of the study}

The subject of this study are motor skills in the first-year students at the Faculty of Security Studies. The main objective of this research is to identify differences in basic motor space between first-year students at the beginning and end of the first semester of the 2018/2019 academic year, that is, to determine whether activities in Sport Skills in Security classes impact the basic motor status in the students at the Faculty of Security Studies. In this way, by measuring the initial and final status of the motor skills status, the conditions for monitoring, control, comparison with the results achieved in the previous measurements, improving the existing battery of tests during the selection process for admission to schooling, as well as improving the existing Sport Skills in Security course curriculum have been created. This research has one general hypothesis with the basic assumption that, after the performance of exercises, the basic motor status in the respondents will improve.

Thus, the assumption is that the implemented program within the contents of the Sport Skills in Security course will have a significant positive impact on the transformation of the students' motor skills and that a statistically significant difference between the initial and final measurements will be obtained.

\section{RESEARCH METHODS}

This study is of an experimental nature, in which the initial and final measurements of motor skills were made. The initial measurement was made at the beginning of the first semester of the 2018/2019 academic year and the final measurement was performed at the end of the first semester. The study was conducted in the athletic hall within the Faculty of Physical Education and Sports in Banja Luka and the FC Borac Athletic Stadium in Banja Luka. The testing was conducted by the teachers of Special Physical Education, Faculty of Security Studies. 


\section{Sampling}

The sample consisted of 31 first-year male students aged 19-20 at the Faculty of Security Studies, who were clinically healthy with no visible physical defects or morphological aberrations and nearly completing morphological and motor development. It should be noted that all respondents had successfully passed the medical examination and psychological tests required for admission to the Faculty of Security Sciences.

\section{Variable sampling}

The sample of variables consists of a battery of seven motor skills tests used in the selection process for admission to the Faculty of Security Studies: standing long jump (MSDM), the number of push-ups in 10 seconds (MSKL), the number of trunk lifts in 30 seconds (MPTR), stick agility (MOKP), somersault - backward somersault - running (MKNT), hand tapping (MTAP) and the Cooper 12-minute run test (MKUP). The first variable was used to assess the explosive power of the leg extensors, the second and third to assess the repetitive upper limb and trunk strength, the fourth to assess body coordination, the fifth to assess agility, the sixth to assess the frequency of arm movement, while the seventh variable used to assess the respondents' aerobic energy potential. A detailed description, the method of implementation, measurement conditions and the norms of the assessment of motor skills are contained in the Rulebook on the implementation of the selection process of candidates for admission to the Faculty of Security Studies.

\section{METHODS OF DATA PROCESSING}

The data obtained in this study were processed by descriptive and comparative statistical procedures. Their mathematical processing was performed using the SPSS program - version 20.00. Using the method of primary data processing, information on the distribution of variables within the space studied was obtained, with the arithmetic mean being determined as a measure of the average of the result values and standard deviation as an indicator of the deviation of the results from the arithmetic mean of the results. The Kolmogorov-Smirnov test was used to test the correctness of the data distribution, while the dependent-samples Student's t-test was used to test the difference of the average values for each variable in the initial and final measurements. In addition to the numerical indicators, a qualitative assessment of the results achieved in the initial and final measurements was conducted. 
RESULTS AND DISCUSSION

Table 1. Results of the initial and final measurements of motor skills

\begin{tabular}{|c|c|c|c|c|c|c|c|c|}
\hline \multirow[b]{2}{*}{ 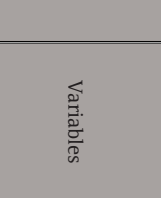 } & \multicolumn{4}{|c|}{ Results of the initial measurement } & \multicolumn{4}{|c|}{ Results of the final measurement } \\
\hline & 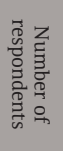 & 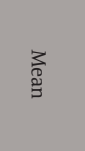 & 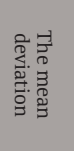 & 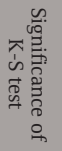 & 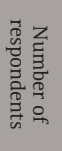 & 艿 & 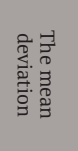 & 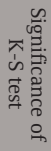 \\
\hline MSDM & 31 & 245.96 & 13.84 & .625 & 31 & 249.00 & 16.31 & .605 \\
\hline MSKL & 31 & $\begin{array}{l}13.48 \\
\end{array}$ & 2.29 & .159 & 31 & $\begin{array}{l}15.38 \\
\end{array}$ & 1.81 & .094 \\
\hline MPTR & 31 & 31.90 & 3.36 & .517 & 31 & 33.03 & 2.76 & .490 \\
\hline MOKP & 31 & 5.84 & .94 & .968 & 31 & 4.99 & $\begin{array}{l}.62 \\
\end{array}$ & .890 \\
\hline MKNT & 31 & 5.94 & .57 & .600 & 31 & 5.44 & .36 & .509 \\
\hline MTAP & 31 & 52.12 & 3.87 & .748 & 31 & 54.32 & $\begin{array}{l}4.57 \\
\end{array}$ & .575 \\
\hline MKUP & 31 & 2854.19 & 284.61 & .646 & 31 & 2749.35 & 274.41 & .743 \\
\hline $\begin{array}{c}\text { NUMBER OF } \\
\text { RESPONDENTS }\end{array}$ & 31 & & & & 31 & & & \\
\hline
\end{tabular}

Table 1 shows the basic central and dispersion results of the initial and final measurements of basic motor skills. As it can be seen in Table 1, the measures of variability indicate a small dispersion of the respondents' individual results in relation to their average values, on the basis of which we can accept the hypothesis that the distribution in all variables is normal, which indicates the fact that it is a very homogeneous set. An examination of the arithmetic mean of the results achieved in the initial and final measurements shows that in the final measurement, in the variables observed, except the Cooper 12-minute run test variable, there was a certain improvement of the results compared to the results achieved in the initial measurement.

Table 2 demonstrates the numerical data of the grades achieved on the motor skill test between the initial and final measurements.

Table 2. Evaluation of the results in the initial and final measurements of motor skills

\begin{tabular}{|c|c|c|c|c|c|c|c|c|c|c|c|c|c|c|}
\hline & \multicolumn{10}{|c|}{ Grades for the initial measurement } & \multicolumn{4}{c|}{ Grades for the final measurement results } \\
\hline Grades & 0 & 1 & 2 & 3 & 4 & 5 & AG & 0 & 1 & 2 & 3 & 4 & 5 & AG \\
\hline MSDM & 0 & 3 & 10 & 4 & 5 & 9 & 3.22 & 0 & 4 & 5 & 7 & 4 & 11 & 3.41 \\
\hline MSKL & 0 & 1 & 4 & 6 & 7 & 13 & 3.87 & 0 & 1 & 0 & 0 & 5 & 25 & $\mathbf{4 . 7 0}$ \\
\hline MPTR & 0 & 0 & 1 & 4 & 7 & 19 & $\mathbf{4 . 4 1}$ & 0 & 0 & 0 & 2 & 7 & 22 & $\mathbf{4 . 6 4}$ \\
\hline MOKP & 0 & 1 & 6 & 10 & 11 & 3 & 3.29 & 0 & 0 & 0 & 4 & 15 & 12 & $\mathbf{4 . 2 5}$ \\
\hline MKNT & 0 & 0 & 5 & 11 & 14 & 1 & 3.35 & 0 & 0 & 0 & 5 & 17 & 9 & $\mathbf{4 . 1 2}$ \\
\hline MTAP & 0 & 0 & 5 & 13 & 6 & 7 & 3.48 & 0 & 1 & 0 & 11 & 6 & 13 & 3.96 \\
\hline MKUP & 3 & 4 & 9 & 7 & 5 & 3 & $\mathbf{2 . 5 1}$ & 6 & 6 & 10 & 5 & 3 & 1 & $\mathbf{1 . 8 7}$ \\
\hline $\begin{array}{c}\text { NUMBER OF } \\
\text { GRADES }\end{array}$ & 3 & 9 & 40 & 55 & 55 & 55 & 3.44 & 6 & 12 & 15 & 34 & 57 & 93 & 3.85 \\
\hline
\end{tabular}

Key: MSDM - standing long jump, MSKL - the number of push-ups in 10 seconds, MPTR - the number of trunk lifts in 30 seconds, MOKP - stick agility, MKNT - 
somersault - backward somersault - running, MTAP - hand tapping, MKUP - the Cooper 12-minute run test, AG - average grade

As shown in Table 2, regarding the first variable (MSDM) - standing long jump, none of the respondents received 0 points in the initial and final measurements. The mean value of the grades in the initial measurement amounts to 3.22 , while in the final amounts to 3.41.

Concerning the MSKL variable - number of push-ups in 10 seconds, none of the respondents received 0 points in the initial and final measurements. The mean value of the grades in the initial measurement amounts to 3.87 , while in the final amounts to 4.70 .

Regarding the MPTR variable (number of carcasses performed in 30 seconds), all respondents received positive grades. The mean value of the grades in the initial measurement amounts to 4.41, while in the final is 4.64 .

In the case of the MOKP variable (stick agility), none of the respondents received 0 points in the initial and final measurements. The mean value of the grades in the initial measurement amounts to 3.29 , while in the final amounts to 4.25

For the MKNT variable (somersault - backward somersault - running), none of the respondents were awarded 0 and 1 grades. The mean value of the grades in the initial measurement amounts to 3.35, while in the final amounts to 4.12 .

With the MTAR variable (hand tapping), none of the respondents were awarded 0 points in the initial and final measurements. The mean value of the grades in the initial measurement is 3.48 , while in the final is 3.96 .

Considering the results of many previous studies that have dealt with similar issues, this result is to be expected. In this case, too, under the influence of the appropriate kinesiologic operators envisaged by the Sports Skills course program, positive transformations have occurred. The data obtained indicate that a number of respondents, after completion of the program, have made significant progress regarding the quality of motor skills. Specifically, it was observed that the respondents who had worse results in the initial measurement made more progress than the respondents who achieved excellent results in the initial measurement. It is believed that the respondents who had worse results in the initial measurement contributed a great deal to the statistically significant differences between the initial and final measurements.

In the final measurement, lower values of the results were found for the MCUP variable (Cooper 12-minute run test) than those achieved by the respondents in the initial measurement. The mean value of the grades in the initial measurement amounted to 2.51, while in the final one was 1.87. A large number of respondents were reported to have performed poorly on this test.

68 Specifically, 3 respondents received 0 points in the initial measurement and 6 respondents in the final measurement. This phenomenon can be explained by a small number of classes pertaining to the development of students' functional skills. Kinesiologic operators which were predominantly represented by the program did not significantly impact the development of functional skills, so their stagnation was also expected, at best. 
Thus, comparing the mean of the grades of the whole system of the variables applied, it is evident that the final measurement, as a result of the implemented program, with the exception of functional skills, the mean values of the results achieved compared to the initial measurement increased.

Table 3 shows the results of the Student's paired samples t-test for the motor skills variables observed after the initial and final measurements.

Table 3. Results of the Student's paired samples t-test concerning motor skills

\begin{tabular}{|c|c|c|c|c|c|c|c|c|c|}
\hline & & & Paire & differences of resu & & & & & \\
\hline & & & & & $95 \%$ trus & t interval & $\frac{9}{8}$ & & $=\sqrt[n]{n}$ \\
\hline Motor sl & lls variables & Mean value & deviation & the mean & Jower limit & Inner limit & $\stackrel{2}{=}$ & \& & ఏ్ \\
\hline Pair 1 & $\begin{array}{c}\text { МСДМ1 - } \\
\text { МСДМ2 }\end{array}$ & -3.03226 & 8.43202 & 1.51444 & -6.12515 & .06063 & -2.002 & 30 & .054 \\
\hline Pair 2 & $\begin{array}{l}\text { МСКЛ1 - } \\
\text { МСКЛL2 }\end{array}$ & -1.90323 & 2.07131 & .37202 & -2.66299 & -1.14346 & -5.116 & 30 & .000 \\
\hline Pair 3 & $\begin{array}{l}\text { МПТР1 - } \\
\text { МПТР2 }\end{array}$ & -1.12903 & 3.25312 & .58428 & -2.32229 & .06422 & -1.932 & 30 & .063 \\
\hline Pair 4 & $\begin{array}{l}\text { МОКП1 - } \\
\text { МОКП2 }\end{array}$ & .84935 & .76309 & .13705 & .56945 & 1.12926 & 6.197 & 30 & .000 \\
\hline Pair 5 & $\begin{array}{c}\text { MKHT1 - } \\
\text { MKHT2 }\end{array}$ & .50161 & .47523 & .08535 & .32730 & .67593 & 5.877 & 30 & .000 \\
\hline Pair 6 & $\begin{array}{l}\text { MTAP1 - } \\
\text { MTAP2 }\end{array}$ & -2.19355 & 3.60943 & .64827 & -3.51750 & -.86960 & -3.384 & 30 & .002 \\
\hline Pair 7 & $\begin{array}{c}\text { МКУП1 - } \\
\text { МКУП2 }\end{array}$ & 104.83871 & 159.16178 & 28.58630 & 46.45770 & 163.21972 & 3.667 & 30 & .001 \\
\hline
\end{tabular}

Key: MSDM1-MSDM2 - standing long jump in the initial and final measurements, MSKL1-MSKL2 - the number of push-ups in 10 seconds in the initial and final measurements, MPTR1-MPTR2 - the number of trunk lifts in 30 seconds in the initial and final measurements, MOKP1-MOKP2 - stick agility in the initial and final measurements, MKNT1-MKNT2 - somersault - backward somersault - running in the initial and final measurements, MTAP1-MTAP2 - hand tapping in the initial and final measurements, MKUP1-MKUP2 - the Cooper 12-minute run test in the initial and final measurements.

The analysis of the results obtained by comparing the difference between the mean values of the results of the motor skill tests on the initial and final testing demonstrated statistically significant differences between the initial and final measurements for the following variables: number of push-ups in $10 \mathrm{sec}-$ onds (MSKL), stick agility (MOCP), somersault - backward somersault - running (MKNT), and hand tapping (MTAP), which is also evident in a higher grade for the score achieved, which resulted in an increase in value by one grade. Quantitative or qualitative changes in favor of the results obtained in the final measurement were also found in the variables used to assess motor skills, in which no statistically significant differences were observed, with the exception of the results obtained on the Cooper 12-minute run test variable (MCI) in which the respondents achieved worse results in the final measurement by one grade.

The analysis of the results obtained indicates that the quantitative changes occurred within motor skills such as strength, coordination, agility, and the frequency of movement, which is largely due to the structuring movement 
mechanism, which can be explained by a larger portion of teaching contents, whose movement structure and execution efficiency is based on these motor skills.

Based on the review of the studies dealing with the transformation of motor characteristics in a similar population of respondents, it may be concluded that similar results were obtained: (Kopaš, 1994; Rodić, 1994; Blagojević, 1997; Mudrić, Božić, Subotički and Baltić, 1998; Amanović, Jovanović and Mudrić; 1999; Arlov,1999; Blagojević, 2002; Janković et al., 2008), who investigated the effects of motor treatments of the Special Physical Education program on changes in motor skills and the dynamics of their transformation.

\section{CONCLUSION}

The aim of this paper was to determine changes in the basic motor status in the first-year students at the Faculty of Security Studies, influenced by systematic exercise as part of the implementation of teaching contents of the Sport Skills in Security course, during the 60-hour course, during the first semester of the 2018/2019 academic year. In the research of motor skills development during the process of regular teaching, seven motor skill tests were used, which are usually used during the selection of candidates for admission to the Faculty of Security Studies.

An experimental longitudinal research method with one group and initial and final measurements was used as the main method in this study. For the purposes of this paper, changes in the given characteristics were examined in a sample of 31 male subjects, aged between 19 and 20, with the assumption that the program contents encompassed by the Sport Skills in Security course will have significant positive impact on the motor skills status in the students at the Faculty of Security science, which was confirmed by this research.

The analysis of the results obtained indicated that the improvement of motor skills was achieved in the following variables: the number of push-ups in 10 seconds (MSKL), stick agility (MOKP), somersault - backward somersault - running (MKNT), and hand tapping (MTAP). Other variables used to assess motor skills, in which no statistically significant differences were observed, also showed quantitative or qualitative changes in favor of the results obtained it the final measurement, with the exception of the results obtained on the Cooper 12-minute run test (MCI), which the respondents scored worse in the final measurement. Considering that the classes were held indoors during the winter semester, which is why the contents aimed at developing functional skills could not be sufficiently practiced, it was not possible to significantly influence the development of this skill.

Finally, it can be noted that owing to the systematic work through the teaching of Sports Skills in Security, there was a significant improvement in the status of basic motor skills in the first-year students at the Faculty of Security Studies in Banja Luka.

Considering the fact that the basic role of the Sport Skills in Security course is to prepare the students at the Faculty of Security Studies for the acquisition and realization of the content of the subject of Special Physical Education in the further education of students, as well as the fact that a number 
of previously published studies found that the effectiveness of acquiring the content of the subject Special Physical Education depends, to a great extent, on students' motor skills, our research findings could be used as useful data in the further education of students when planning and programing teaching contents of the subject Special Physical Education.

\section{REFERENCES}

Амановић, Ђ., Јовановић,С., Мудрић, Р. (1999). Утицај програма Специјалног физичког образовања на базичне моторичке способности полицајаца приправника. Безбједност 41(6), 778-793.

Амановић, Ђ., Мудрић, Р., Јовановић, С. (2002). Развој различитих видова силе под утицајем програма Специјалног физичког образовања код студената Више школе унутрашњих послова. У: Зборник радова наставника ВШУП 6 (53-70). Земун: ВШУП.

Амановић, Ђ., Милошевић, М., Мудрић, Р. (2004). Методе и средства за процјену, праћење и развој мишићне силе у Специјалном физичком образовању. Београд: Инпресс.

Арлов, Д. (1999). Ефекти третмана Специјалног физичког образовања на базично - моторичке и специфично моторичке способности студената. Необјављена докторска дисертација. Нови Сад: Факултет физичког васпитања Универзитета у Новом Саду.

Благојевић, М., Ћирковић, 3., Милошевић, М., Стојчић, Р., Јовановић, С., Арлов, Д., и Допсај, М. (1994). Утицај неких адаптационих карактеристика приправника милиционара на ефекте учења моторичких алгоритама и програма у Специјалном физичком образовању. У: Зборник радова првог савјетовања из Специјалног физичког образовања Полицијске академије у Београду (49-56). Београд: Полицијска академија.

Благојевић, М. (1996). Утицај морфолошких и моторичких карактеристика полицајаца на ефикасност учења џудо техника. Београд: Полицијска академија.

Благојевић, М. (1997). Утицај одређених моторичких третмана Специјалног физичког образовања на промјену морфолошких и моторичких карактеристика студената Полицијске академије. Необјављена докторска дисертација. Београд: Факултет физичке културе.

Благојевић, М. (2002). Утицај наставе Специјалног физичког образовања на промјене морфолошких и моторичких карактеристика студената Полицијске академије. Београд: Министарство за НИТ Републике Србије.

Божић, С., Милошевић, М., Зулић, М. (1990). Утицај неких антрополошких карактеристика радника на структурирање моторичких алгоритама у Специјалном физичком образовању. Специјално физичко образовање, 2, $128-135$. 
Гужвица, М. (2005). Повезаност неких координационих способности са нивоом усвојености техника из програма специјалног физичког образовања. Безбједност, полиција, грађани, 2, 353-361.

Гужвица, М. (2006). Валоризација новог модела ситуационо - моторичке обуке студената Високе школе унутрашњих послова. Необјављена докторска дисертација. Београд: Факултет спорта и физичког васпитања Универзитета у Београду.

Гужвица, М. (2007). Предикција утицаја латентних моторичких способности и морфолошких карактеристика на успјешност извођења техника из програма специјалног физичког образовања. Безбједност, полиција, грађани, 1, 879-890.

Гужвица, М. (2008). Латенте моторичке структуре значајне за извођење удараца челом песнице Безбједност, полиција, грађани, 1, 21-30.

Dopsaj, M., Milošević, M., Arlov, D., Blagojević, M., Stefanović, Đ. (1996). The structure of changes in mehanic contractile characteristic of leg extensor muscles caused by combined strenght training during one-year motor learning program in Special physical education. In: Proceeding of International Congress on Sport Psychology (pp.313-318). Komotini, Greece.

Dopsaj, M., Milošević, M., Blagojević, M., \& Mudrić, R. (2002). A new approach to discriminating athletes according to their specific fitness status when considering isometric force characteristics. In: Hakkkinen K., Tihanyi J. (ed.) 3rd International conference on strength training, - Abstract book. (pp. 7778). Budapest: Semmelweis University Faculty of Physical Education and Sport Sciences.

Јанковић, Р., Коропановски, Н., Вучковић, Г., Димитријевић, Р., Атанасов, Д., Миљуш, Д., Маринковић, Б., Ивановић, Ј., Благојевић, М. и Допсај, М. (2008). Тренд промене основних антропометријских карактеристика студената Криминалистичко-полицијске академије у току студија. Наука, безбедност, полиција 13 (2), 137-152.

Јанковић, Р., Вучковић, Г., Благојевић, М. (2014). Утврђивање норматива за процену специфичне спретности полицајаца за студенте Криминалистичкополицијске академије. Безбедност, 56 (2), 65-76.

Копаш, Ј. (1994).Утицај часова специјалног физичког образовања на базични моторички статус полазника курса за милиционаре приправнике на Клиси. У: Зборник радова првог савјетовања из Специјалног физичког образовања Полицијске академије у Београду (147 -153). Београд: Полицијска академија.

72 Милошевић, М. (1985). Одређивање структуре моторичких својстава милиционара. Земун: Виша школа унутрашњих послова.

Милошевић, М., Јовановић, С., Стојичић, Р., Арлов, Д., Благојевић, М., Допсај, М. (1994). Модел едукације у специјалном физичком образовању. У: Зборник 
радова првог савјетовања из Специјалног физичког образовања Полицијске академије у Београду (стр.9-22). Београд: Полицијска академија.

Милошевић, М., Мудрић, Р., Амановић, Ђ. (2003): Методе и средства за развој мишићне силе у спорту. У: Зборник радова са 3. научно стручног симпозијума. Наука и карате спорт. (стр. 83-88). Нови Сад: Карате савез Војводине.

Мудрић, Р., Јовановић, С., Милошевић, М., и ћирковић, 3. (1994). Предлог батерије тестова за процену сложених структура карате техника у фази усмерене обуке у СФО-у. У: Зборник радова првог савјетовања из Специјалног физичког образовања Полицијске академије у Београду (124-133). Београд: Полицијска академија.

Мудрић, Р., Божић, С., Суботички, С., и Балтић, Р. (1998). Резултати праћења базичних моторичких способности студената ВШУП-а у Земуну. У: Зборник радова наставника ВШУП (219-225). Београд: Виша школа унутрашњих послова.

Паспаљ, Д. (2008). Утицај базичних моторичких способности на ефикасност извођења техника бацања из програма Специјалног физичког образовања. Необјављен магистарски рад. Бања Лука: Факултет физичког васпитања и спорта Универзитета у Бањој Луци.

Паспаљ, Д. (2009). Латентне моторичке структуре значајне за извођење технике чишћења наступајуће ноге из програма Специјалног физичког образовања. Безбједност, Полиција, Грађани 1, 173-186.

Паспаљ, Д. (2010). Ефекти различитих континуитета наставе на ниво усвојености техника падова, чишћења и бацања из програма специјалног физичког образовања. Безбједност, полиција, грађани 3-4, 513-522.

Паспаљ, Д. (2012). Разлике у неким моторичким способностима студената Високе школе унутрашњих послова с обзиром на ефикасност извођења одбране од напада штапом одозго. Безбједност, полиција, грађани, 3-4, 467-478.

Паспаљ, Д. (2013). Полни диморфизам антрополошког профила студената Високе школе унутрашњих послова у функцији рјешавања проблемских ситуација из Специјалног физичког образовања. Безбједност, полиција, грађани, 3-4, 167-180.

Родић, Н. (1994). Утицај програма физичке обуке војника на њихове физичке способности. У: Зборник радова првог савјетовања из Специјалног физичког образовања Полицијске академије у Београду (115-123). Београд: Полицијска академија.

Стојчић, Р. (1994). Одређивање моторичке ефикасности припадника специјалних јединица. Необјављен магистарски рад. Београд: Факултет физичке културе, Универзитета у Београду. 
Суботички, С. (2003). Повезаност морфолошких и моторичких карактеристика студената ВШУП са ефикасношћу реализације техника каратеа из програма Специјалног физичког образовања. Необјављен магистарски рад. Нови Сад: Факултет физичке културе Универзитета у Новом Саду.

Paper received on: 29. 09. 2019.

Paper acceptted for publishing on: 22. 11. 2019. 


\title{
УТИЦАЈ ПРОГРАМА НАСТАВНОГ ПРЕДМЕТА СПОРТСКЕ ВЈЕШТИНЕ У БЕЗБЈЕДНОСТИ НА БАЗИЧНИ МОТОРИЧКИ СТАТУС СТУДЕНАТА ФАКУЛТЕТА БЕЗБЈЕДНОСНИХ НАУКА
}

Оригинални научни рад

\begin{tabular}{|l|l|l|}
\hline DOI 10.5937/zurbezkrim1902065P & COBISS.RS-ID 8630040 & УДК 355.233.22-057.36:796.9 \\
\hline
\end{tabular}

\author{
Дарко Паспаљ ${ }^{1}$ \\ Факултет безбједносних наука, Универзитет у Бањој Луци \\ Милан Гужвица \\ Факултет безбједносних наука, Универзитет у Бањој Луци \\ Лазар Вулин \\ Факултет безбједносних наука, Универзитет у Бањој Луци
}

Апстракт: Истраживање је спроведено с циљем да се примјеном експерименталне методе утврди да ли програм физичког вјежбања на настави из наставног предмета Спортске вјештине у безбједности, у редовним условима рада, може резултирати значајним промјенама у моторичким способностима студената Факултета безбједносних наука из Бања Луке. Истраживање је спроведено у току школске 2018/2019. године, кроз фонд од 60 наставних часова, на узорку од 31. студента прве године Факултета безбједносних наука, мушког пола, старосне доби између 19 и 20 година, са иницијалним мјерењем на почетку и финалним мјерењем на крају првог семестра. Узорак варијабли је чинило седам тестова моторичких способности који се користе приликом провођења процеса селекције кандидата за упис на школовање на Факултету безбједносних наука. Примјеном Студентовог т теста за зависне узорке, утврђено је да су под утицајем програмираног вјежбања добијене статистички значајне разлике у статусу моторичких способности студената између иницијалног и финалног мјерења, код варијабли: број урађених склекова за 10 секунди (МСКЛ), окретност са палицом (МОКП), колут напријед - колут назад - трчање (МКНТ) и тапинг руком (МТАП), чиме је основна хипотеза дјеломично потврђена. Резултати овог истраживања могли би да буду корисна информација за даљу едукацију, односно за планирање и програмирање наставних садржаја из наставног предмета Специјално физичко образовање.

Кључне ријечи: студенти, спортске вјештине, редовна настава, моторичке способности.

1 Аутор за кореспонденцију: др Дарко Паспаљ, доцент на Факултету безбједносних наука, Универзитет у Бањој Луци. E-mail: darko.paspalj@fbn.unibl.org 


\section{УВОД}

Предмет Спортске вјештине у безбједности је конституисан на Факултету безбједносних наука у Бањој Луци, с основним циљем развоја и усавршавања природних облика кретања за које је кроз искуство и праксу примијећено да нису у ранијем периоду развоја дјеце, сада студената, усвојена до нивоа који би им омогућио брже и ефикасније усвајање сложенијих форми кретања. Кроз усавршавање природних облика кретања, на основу научних сазнања, реално је претпоставити да ће креирани програм из предмета Спортске вјештине у безбједности, утицати и на развој моторичких способности и морфолошких карактеристика, које су значајне за даљу едукацију, односно, за усвајање садржаја из предмета Специјално физичко образовање. Ова претпоставка је заснована на бројним научним истраживањима, која тврде да оптимални ниво моторичких способности и морфолошких карактеристика доприносе, не само бржем учењу и усвајању сложених моторичких програма из Специјалног физичког образовања, већ и могућности њихове практичне примјене у реалној животној ситуацији: (Милошевић, 1985; Божић, Милошевић и Зулић, 1990; Милошевић и сарадници, 1994; Благојевић и сарадници, 1994; Мудрић, Јовановић, Милошевић и Ћирковић, 1994; Стојичић, 1994; Благојевић, 1996; 1997; Допсај, Милошевић, Арлов, Благојевић и Стефановић, 1996; Милошевић, Мудрић и Амановић, 2002; Допсај, Милошевић, Благојевић и Мудрић, 2002; Амановић, Мудрић и Јовановић, 2002, Суботички, 2003; Амановић, Милошевић и Мудрић, 2004; Гужвица, 2005; 2006; 2007; 2008; Паспаљ, 2008; $2009 ; 2010 ; 2012 ; 2013 ;$ Јанковић, Вучковић и Благојевић, 2014).

Дакле, Спортске вјештине у безбједности се као наставна дисциплина у плану и програму Факултета безбједносних наука изучавају као изборни наставни предмет који има за циљ да развија морфолошке карактеристике, моторичке и функционалне способности као и друга знања која су неопходна за успјешно обављање безбједносних послова. Предмет се изучава на првој години студија кроз 15 седмица у фонду од 60 часова, са седмичним фондом од 4 часа. Циљ предмета је да се осмишљеним наставним процесом омогући студентима Факултета безбједносних наука, стицање и развој моторичких способности значајних за успјешно учење, савладавање и обављање активности карактеристичних за будуће раднике безбједносних послова. Поред овога, циљ је да се на основу савремених научних, теоријских и практичних сазнања студенти упознају са начинима рјешавања једноставних и сложених ситуација и препрека у очекујућим просторним и временским условима, као и унапређењу њиховог здравља.

Очекивани исход предмета је да се у потпуности усвоје биотичка кретања, развију моторичке и функционалне способности, унаприједе морфолошке карактеристике које ће позитивно утицати на лакше савладавање специфичних знања и вјештина карактеристичних за обављање сложених моторичких проблема, са којима се будући радник безбједносних послова у свом професионалном раду може срести. Студенти кроз наставне садржаје реализују физичке активности усмјерене на развој: издржљивости, силе-снаге, брзине, координације, флексибилности, агилности, реактивности и равнотеже, док се посебна пажња посвећује развоју знања ради савладавања хоризонталних и вертикалних препрека у лабораторијским и 
реалним условима као и савладавању дубоких и мирних водених површина, пливањем и роњењем те спасавању утопљеника у плиткој и дубокој води.

Од предвиђених 60 наставних часова, 15 часова се реализује на Градском олимпијском базену кроз усавршавање одређених знања за савладавање дубоких и мирних површина пливањем и роњењем, 15 часова се реализује у сали за борилачке спортове Факултета физичког васпитања и спорта са циљем унапређења основних елемената гимнастике и акробатике (са задатком развоја окретности и осјећаја у простору), док се 30 наставних часова реализује у атлетском хангару Факултета физичког васпитања и спорта Универзитета у Бањој Луци, са циљем унапређења статуса моторичких способности, доминантно: координације, силе и снаге, брзине, издржљивости, флексибилности, агилности, реактивности и равнотеже.

Програм је, дакле, обухватао оне кинезиолошке активности које су заступљене у редовном програму. То су природни облици кретања са одређеним задацима и различитим облицима кретања, те комплекс вјежби обликовања појединачно и у паровима. Тренажни процес на развоју базичних моторичких способности се реализовао кроз рад са властитом тежином и рад са реквизитима и на справама, при чему је примјењиван кружни метод рада и рад по станицама, као и рад на савладавању полигона са препрекама. Савладавање препрека је вршено природним облицима кретања, што значи да су одређени број препрека студенти морали савладати у затвореном простору без станке у што краћем временском периоду. Код реализације поменутих садржаја примјењивани су најприје једноставни, а потом и сложени методичко-организацијски облици рада. У програм нису ушла тестирања и мјерења те су она вршена прије и послије примјене програма.

\section{Предмети и ииљ истираживања}

Предмет истраживања су моторичке способности студената прве године Факултета безбједносних наука. Основни циљ овог истраживања је да се утврде разлике у базичном моторичком простору између студената прве године Факултета безбједносних наука на почетку и на крају првог семестра студија школске 2018/2019. године, тј. да се утврди да ли активности на часовима наставе предмета Спортске вјештине у безбједности утичу на базични моторички статус студената Факултета безбједносних наука. На овакав начин мјерењем иницијалног и финалног стања статуса моторичких способности, створени су услови за праћење, контролу, упоређивање са резултатима оствареним у ранијим мјерењима, усавршавање постојеће батерије тестова код провођења процеса селекције за пријем на школовање, као и усавршавања постојећег наставног плана и програма наставног предмета Спортске вјештине у безбједности. Истраживање има једну генералну хипотезу са основном претпоставком по којој ће у систему базичног моторичког статуса испитаника, након примјењеног вјежбања, доћи до њиховог побољшања.

Наиме, претпоставка је да ће проведени програм и програмски садржаји наставног предмета Спортске вјештине у безбједности у значајној мјери позитивно утицати на трансформацију моторичких способности 
студената и да ће се добити статистички сигнификантна разлика између иницијалног и финалног мјерења.

\section{МЕТОДЕ ИСТРАЖИВАЬА}

Истраживање је експерименталног карактера у којем је вршено иницијално и финално мјерење моторичких способности. Иницијално мјерење је вршено на почетку првог семестра школске 2018/2019. године, а финално на крају првог семестра. Истраживање је спроведено у атлетској дворани Факултета физичког васпитања и спорта у Бањој Луци и на атлетском стадиону ФК Борац из Бања Луке. Тестирање су спровели наставници Специјалног физичког образовања, Факултета безбједносних наука.

\section{Узорак исиичйаника}

Узорак испитаника чинили су студенти прве године (31 студент) Факултета безбједносних наука, мушког пола, старосне доби између 19 и 20 година, клинички здрави, без видљивих тјелесних недостатака или морфолошких аберација, који се налазе при крају морфолошког и моторичког развоја. Потребно је напоменути да су сви испитаници претходно успјешно прошли љекарски преглед и психолошке тестове за студирање на Факултету безбједносних наука.

\section{Узорак варијабли}

Узорак варијабли чини батерија од седам тестова моторичких способности који се користе приликом провођења процеса селекције кандидата за упис на школовање на Факултету безбједносних наука: скок удаљ из мјеста (МСДМ), број урађених склекова за 10 секунди (МСКЛ), број урађених подизања трупа за 30 секунди (МПТР), окретност са палицом (МОКП), колут напријед - колут назад - трчање (МКНТ), тапинг руком (МТАР) и Куперов тест трчања 12 минута (МКУП). Прва варијабла служи за процјену експлозивне снаге опружача ногу, друга и трећа за процјену репетитивне снаге горњих екстремитета и трупа, четврта за процјену координације тијела, пета за процјену окретности и агилности, шеста за процјену фреквенције покрета руком, док седма служи за процјену аеробног енергетског потенцијала испитаника. Детаљан опис, начин извођења, услови мјерења и нормативи процјене моторичких способности дати су у Правилнику о провођењу процеса селекције кандидата за упис на школовање на Факултет безбједносних наука.

\section{МЕТОДЕ ОБРАДЕ ПОДАТАКА}

Подаци добијени истраживањем обрађени су дескриптивним и компаративним статистичким процедурама. Њихово математичко процесирање реализовано је уз употребу програма SPSS - верзија 20.00. Примјеном методе примарне обраде података добијене су информације о 
дистрибутивности варијабли у оквиру испитиваног простора, при чему је одређена аритметичка средина, као мјера просјека вриједности резултата и стандардна девијација као мјера показатеља одступања резултата од средње вриједности резултата. У циљу тестирања правилности дистрибуције података коришћен је Колмогоров-Смирнов тест, док је за тестирање разлике просјечних вриједности по промјењивима на иницијалном и финалном мјерењу коришћен Студентов-т тест за зависне узорке. Поред бројчаних показатеља, извршена је и квалитативна процјена остварених резултата на иницијалном и финалном мјерењу.

\section{РЕЗУЛТАТИ И ДИСКУСИЈА}

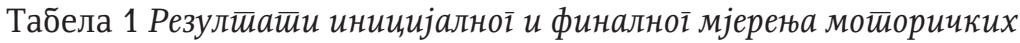
сйособностй

\begin{tabular}{|c|c|c|c|c|c|c|c|c|}
\hline \multirow[b]{2}{*}{ 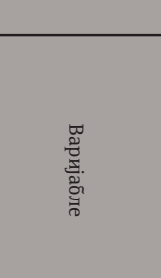 } & \multicolumn{4}{|c|}{ Резултати иницијалног мјерења } & \multicolumn{4}{|c|}{ Резултати финалног мјерења } \\
\hline & 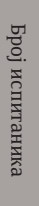 & 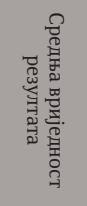 & 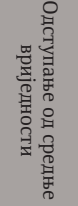 & 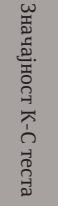 & 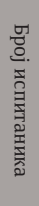 & 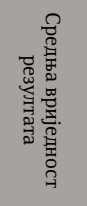 & 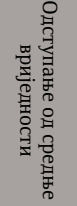 & 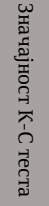 \\
\hline МСДМ & 31 & 245.96 & 13.84 & .625 & 31 & 249.00 & 16.31 & .605 \\
\hline МСКЛ & 31 & 13.48 & 2.29 & .159 & 31 & 15.38 & 1.81 & .094 \\
\hline МПТР & 31 & 31.90 & 3.36 & .517 & 31 & 33.03 & 2.76 & .490 \\
\hline МОКП & 31 & 5.84 & .94 & .968 & 31 & 4.99 & .62 & .890 \\
\hline MКHT & 31 & 5.94 & .57 & .600 & 31 & 5.44 & .36 & .509 \\
\hline MTAP & 31 & 52.12 & 3.87 & .748 & 31 & 54.32 & 4.57 & .575 \\
\hline МкУП & 31 & 2854.19 & 284.61 & .646 & 31 & 2749.35 & 274.41 & .743 \\
\hline $\begin{array}{c}\text { БРОЈ } \\
\text { ИСПИТАНИКА }\end{array}$ & 31 & & & & 31 & & & \\
\hline
\end{tabular}

У Табели 1 приказани су основни централни и дисперзиони резултати иницијалног и финалног мјерења базичних моторичких способности. Прегледом табеле уочава се да мјере варијабилности указују на малу растуреност индивидуалних резултата испитаника од њихових просјечних вриједности, на основу чега можемо прихватити хипотезу да је расподјела код свих варијабли нормална, што указује на чињеницу да се ради о изразито хомогеном скупу. Прегледом средњих вриједности остварених резултата на иницијалном и финалном мјерењу, може се уочити да је на финалном мјерењу у свим праћеним варијаблама, изузев код варијабле Куперов тест трчања 12 минута, дошло до одређеног побољшања резултата у односу на резултате остварене на иницијалном мјерењу.

У Табели 2 приказани су нумерички подаци оцјена остварених на провјери моторичких способности између иницијалног и финалног мјерења. 


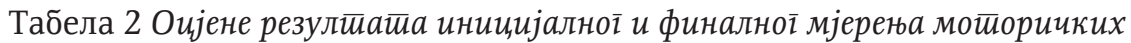

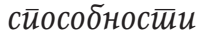

\begin{tabular}{|c|c|c|c|c|c|c|c|c|c|c|c|c|c|c|}
\hline \multirow[b]{2}{*}{ Оцјене } & \multicolumn{7}{|c|}{$\begin{array}{c}\text { Оцјене резултата иницијалног } \\
\text { мјерења }\end{array}$} & \multicolumn{7}{|c|}{ Оцјене резултата финалног мјерења } \\
\hline & 0 & 1 & 2 & 3 & 4 & 5 & $\mathrm{CO}$ & 0 & 1 & 2 & 3 & 4 & 5 & $\mathrm{CO}$ \\
\hline МСДМ & 0 & 3 & 10 & 4 & 5 & 9 & 3.22 & 0 & 4 & 5 & 7 & 4 & 11 & 3.41 \\
\hline МСКЛ & 0 & 1 & 4 & 6 & 7 & 13 & 3.87 & 0 & 1 & 0 & 0 & 5 & 25 & 4.70 \\
\hline МПТР & 0 & 0 & 1 & 4 & 7 & 19 & 4.41 & 0 & 0 & 0 & 2 & 7 & 22 & 4.64 \\
\hline МОКП & 0 & 1 & 6 & 10 & 11 & 3 & 3.29 & 0 & 0 & 0 & 4 & 15 & 12 & 4.25 \\
\hline МКНТ & 0 & 0 & 5 & 11 & 14 & 1 & 3.35 & 0 & 0 & 0 & 5 & 17 & 9 & 4.12 \\
\hline MTAP & 0 & 0 & 5 & 13 & 6 & 7 & 3.48 & 0 & 1 & 0 & 11 & 6 & 13 & 3.96 \\
\hline МКУП & 3 & 4 & 9 & 7 & 5 & 3 & 2.51 & 6 & 6 & 10 & 5 & 3 & 1 & 1.87 \\
\hline $\begin{array}{c}\text { БРОЈ } \\
\text { ОЦЈЕНА }\end{array}$ & 3 & 9 & 40 & 55 & 55 & 55 & 3.44 & 6 & 12 & 15 & 34 & 57 & 93 & 3.85 \\
\hline
\end{tabular}

Легенда: МСДМ - скок удаљ из мјеста, МСКЛ - број склекова за 10 секунди, МПТР - број подизања трупа за 30 секунди, МОКП - окретност са палицом, МКНТ - колут напријед - колут назад - трчање, МТАП - тапинг руком, МКУП - Купер тест трчања 12 минута, СО - средња оцјена.

Из табеле је видљиво да код прве варијабле скок удаљ из мјеста (МСДМ) ниједан од испитаника код иницијалног и финалног мјерења није оцијењени са 0 бодова. Средња вриједност оцјена код иницијалног мјерења je 3,22 а код финалног 3,41.

Код варијабле број урађених склекова за 10 секунди (МСКЛ), такође нико од испитаника код иницијалног и финалног мјерења није оцијењен са 0 бодова. Средња вриједност оцјена код иницијалног мјерења је 3,87 а код финалног 4,70.

Код варијабле број урађених подизања трупа за 30 секунди (МПТР), сви испитаници су добили позитивне оцјене. Средња вриједност оцјена код иницијалног мјерења је 4,41, а код финалног 4,64.

Код варијабле окретност са палицом (МОКП), ниједан испитаник на иницијалном и финалном мјерењу није оцијењен са 0 бодова. Средња вриједност оцјена код иницијалног мјерења је 3,29, а код финалног 4,25.

Код варијабле колут напријед - колут назад - трчање (МКНТ), ниједан испитаник није оцијењен са оцјенама 0 и 1. Средња вриједност оцјена код иницијалног мјерења је 3,35, а код финалног 4,12.

Код варијабле тапинг руком (МТАР), ниједан испитаник на иницијалном и финалном мјерењу није оцијењен са 0 бодова. Средња вриједност оцјена код иницијалног мјерења је 3,48, а код финалног 3,96. 
Овакав резултат је и очекујући, уколико се узму у обзир резултати многобројних досадашњих истраживања која су се бавила сличном проблематиком. Тако су се и у овом случају, под утицајем одговарајућих кинезиолошких оператора предвиђених планом и програмом из предмета Спортске вјештине у безбједности десиле позитивне трансформације. Добијени подаци указују да је одређени број испитаника, под утицајем програма, постигао значајан напредак у квалитету моторичких способности. Наиме, примијећено је да су испитаници који су имали лошије резултате на иницијалном мјерењу, више напредовали од испитаника који су и на иницијалном мјерењу показали завидне резултате. Вјерује се да су испитаници који су имали лошије резултате на иницијалном мјерењу, највише допринијели статистички значајним разликама између иницијалног и финалног мјерења.

Код варијабле Куперов тест трчања 12 минута (МКУП) на финалном мјерењу су добијене ниже вриједности резултата од оних које су испитаници показали на иницијалном мјерењу. Средња вриједност оцјена код иницијалног мјерења је 2,51 а код финалног 1,87. Евидентиран је већи број испитаника који су на овом тесту показали лош резултат. Наиме, на иницијалном мјерењу 3 испитаника су оцијењена са 0 бодова, а на финалном 6 испитаника. Ову појаву је могуће објаснити малим бројем часова који су се односили на развој функционалних способности студената. Кинезиолошки оператери који су доминантно били заступљени програмом нису битно утицали на развој функционалних способности, тако да је, у најбољем случају, била и очекивана њихова стагнација.

Дакле, упоређујући средње вриједности оцјена цијелог система примијењених варијабли, видљиво је да је код финалног мјерења, као посљедица проведеног програма, изузев функционалних способости, дошло до повећања средње вриједности оцјене остварених резултата у односу на иницијално мјерење.

У даљој процедури у Табели 3 приказани су резултати Студентовог т теста за упарене узорке за посматране варијабле моторичких способности након иницијалног и финалног мјерења.

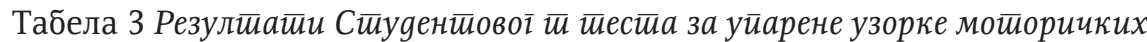

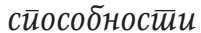

\begin{tabular}{|c|c|c|c|c|c|c|c|c|c|}
\hline \multirow{3}{*}{\multicolumn{2}{|c|}{$\begin{array}{c}\text { Варијабле } \\
\text { моторичких } \\
\text { способности }\end{array}$}} & \multicolumn{5}{|c|}{ Упарене разлике резултата } & \multirow{4}{*}{ 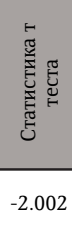 } & \multirow{4}{*}{ 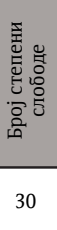 } & \multirow{4}{*}{ 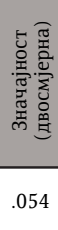 } \\
\hline & & \multirow{3}{*}{$\begin{array}{c}\text { Средња } \\
\text { вриједност } \\
\text { резултата } \\
-3.03226\end{array}$} & \multirow{3}{*}{$\begin{array}{c}\text { Одступање } \\
\text { од средње } \\
\text { вриједности } \\
8.43202\end{array}$} & \multirow{3}{*}{$\begin{array}{c}\text { Стандардна } \\
\text { грешка средње } \\
\text { вриједности } \\
\text { Доња граница }\end{array}$} & \multicolumn{2}{|c|}{$\begin{array}{c}\text { 95\% интервал } \\
\text { повјерења }\end{array}$} & & & \\
\hline & & & & & Доња & Горња & & & \\
\hline Пар 1 & $\begin{array}{l}\text { МСДМ1 - } \\
\text { МСДМ2 }\end{array}$ & & & & -6.12515 & .06063 & & & \\
\hline Пар 2 & $\begin{array}{l}\text { МСКЛ1 - } \\
\text { МСКЛL2 }\end{array}$ & -1.90323 & 2.07131 & .37202 & -2.66299 & -1.14346 & -5.116 & 30 & .000 \\
\hline Пар 3 & $\begin{array}{l}\text { МПТР1 - } \\
\text { МПТР2 }\end{array}$ & -1.12903 & 3.25312 & .58428 & -2.32229 & .06422 & -1.932 & 30 & .063 \\
\hline Пар 4 & $\begin{array}{l}\text { МОКП1 - } \\
\text { МОКП2 }\end{array}$ & .84935 & .76309 & .13705 & .56945 & 1.12926 & 6.197 & 30 & .000 \\
\hline Пар 5 & $\begin{array}{l}\text { МКНТ1 - } \\
\text { МКНТ2 }\end{array}$ & .50161 & .47523 & .08535 & .32730 & .67593 & 5.877 & 30 & .000 \\
\hline
\end{tabular}




\begin{tabular}{|c|c|c|c|c|c|c|c|c|c|}
\hline & & \multicolumn{5}{|c|}{ Упарене разлике резултата } & \multirow{3}{*}{ 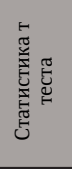 } & \multirow{3}{*}{ 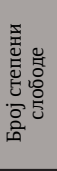 } & \multirow{3}{*}{ 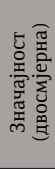 } \\
\hline \multirow{2}{*}{\multicolumn{2}{|c|}{$\begin{array}{c}\text { Варијабле } \\
\text { моторичких } \\
\text { способности }\end{array}$}} & \multirow{2}{*}{$\begin{array}{c}\text { Средња } \\
\text { вриједност } \\
\text { резултата }\end{array}$} & \multirow{2}{*}{$\begin{array}{c}\text { Одступање } \\
\text { од средње } \\
\text { вриједности }\end{array}$} & \multirow{2}{*}{$\begin{array}{c}\text { Стандардна } \\
\text { грешка средње } \\
\text { вриједности } \\
\text { Доња граница }\end{array}$} & \multicolumn{2}{|c|}{$\begin{array}{c}\text { 95\% интервал } \\
\text { повјерења }\end{array}$} & & & \\
\hline & & & & & $\begin{array}{c}\text { Доња } \\
\text { граница }\end{array}$ & $\begin{array}{c}\text { Горња } \\
\text { граница }\end{array}$ & & & \\
\hline Пар 6 & $\begin{array}{l}\text { MTAP1 - } \\
\text { MTAP2 }\end{array}$ & -2.19355 & 3.60943 & .64827 & -3.51750 & -.86960 & -3.384 & 30 & .002 \\
\hline Пар 7 & $\begin{array}{c}\text { МКУП1 - } \\
\text { МКУП2 }\end{array}$ & 104.83871 & 159.16178 & 28.58630 & 46.45770 & 163.21972 & 3.667 & 30 & .001 \\
\hline
\end{tabular}

Легенда: МСДM1 -MSDM2- скок удаљ из мјеста на иницијалном и финалном мјерењу, МСКЛ1 - МСКЛ2 - број склекова за 10 секунди на иницијалном и финалном мјерењу, МПТР1 - МПТР2 - број подизања трупа за 30 секунди на иницијалном и финалном мјерењу, МОКП1 - МОКП2 - окретност са палицом на иницијалном и финалном мјерењу, МКНТ1 - МКНТ2 колут напријед - колут назад - трчање на иницијалном и финалном мјерењу, МТАП1 - МТАП2 - тапинг руком на иницијалном и финалном мјерењу, МКУП1 - МКУП2 - Купер тест трчања 12 минута на иницијалном и финалном мјерењу.

На основу резултата добијених упоређивањем разлика средњих вриједности остварених резултата код провјере моторичких способности на иницијалном и финалном тестирању, утврђено је да су статистички значајне разлике између иницијалног и финалног мјерења остварене код варијабли: број урађених склекова за 10 секунди (МСКЛ), окретност са палицом (МОКП), колут напријед - колут назад - трчање (МКНТ) и тапинг руком (МТАП), што је видљиво и код пораста оцјене остварених резултата, којом приликом је код наведених варијабли дошло до пораста вриједности за једну оцјену. Код осталих варијабли за процјену моторичких способности, код којих нису утврђене статистички значајне разлике остварених резултата, такође је дошло до квантитативних или квалитативних промјена у корист резултата остварених на финалном мјерењу, изузев резултата остварених код варијабле Куперов тест трчања за 12 минута (МКУП), код које су испитаници остварили лошији резултат на финалном мјерењу за једну оцјену.

Анализом остварених резултата видимо да су се квантитативне промјене кретале у склопу моторичких способности снаге, координације, агилности и фреквенције покрета за шта је у највећој мјери задужен механизам за структурирање кретања, што је могуће објаснити већим удјелом наставних садржаја, чија се структура кретања и ефикасност извођења заснива баш на овим моторичким способностима.

Прегледом досадашњих истраживања (Копаш, 1994; Родић, 1994; Благојевић, 1997; Мудрић, Божић, Суботички и Балтић, 1998; Амановић, Јовановић и Мудрић, 1999; Арлов (1999; Благојевић, 2002; Јанковић и сарадници, 2008), која су се бавила трансформацијом моторичких карактеристика на сличној популацији испитаника истраживан је утицај

72 моторичких третмана програма Специјалног физичког образовања на промјене моторичких способности и динамику њиховог трансформисања. 


\section{ЗАКЉУЧАК}

Циљ овог рада је да се код студената прве године Факултета безбједносних наука утврде промјене базичног моторичког статуса, под утицајем систематског вјежбања у склопу реализације наставних садржаја на наставном предмету Спортске вјештине у безбједности, кроз фонд од 60 наставних часова, у току првог семестра школске 2018/2019. године. За истраживање развоја моторичких способности у процесу редовне наставе, примијењено је седам тестова моторичких способности, који се користе приликом провођења процеса селекције кандидата за упис на школовање на Факултету безбједносних наука.

Као главни метод у овом раду примијењен је експериментални истраживачки метод лонгитудиналног истраживања са једном групом и иницијалним и финалним мјерењем. За потребе овог рада, промјене датих својстава су испитиване на узорку од 31. испитаника мушког пола, старосне доби између 19 и 20 година, са претпоставком да ће програмски садржаји наставног предмета Спортске вјештине у безбједности у значајној мјери позитивно утицати на статус моторичких способности студената Факултета безбједносних наука, што се истраживањем и потврдило.

Анализом добијених резултата утврђено је да је побољшање моторичких способности остварено код варијабли: број урађених склекова за 10 секунди (МСКЛ), окретност са палицом (МОКП), колут напријед - колут назад - трчање (МКНТ) и тапинг руком (МТАП). Код осталих варијабли за процјену моторичких способности, код којих нису утврђене статистички значајне разлике остварених резултата, такође је дошло до квантитативних или квалитативних промјена у корист резултата остварених на финалном мјерењу, изузев резултата остварених код варијабле Куперов тест трчања за 12 минута (МКУП), код које су испитаници остварили лошији резултат на финалном мјерењу. С обзиром на то да се настава реализовала у току зимског семестра у затвореном простору, због чега се нису у довољној мјери могли упражњавати садржаји за развој функционалних способности, није се могло значајније ни утицати на развој ове способности.

На крају рада се може констатовати да је захваљујући систематском раду кроз реализацију наставе на часовима Спортских вјештина у безбједности, дошло до значајног побољшања статуса базичних моторичких способности студената прве године Факултета безбједносних наука у Бањој Луци.

Имајући у виду чињеницу да је основна улога наставног предмета Спортске вјештине у безбједности да студенте Факултета безбједносних наука припреми за усвајање и реализацију наставних садржаја из наставног предмета Специјално физичко образовање у наставку даљег школовања, као и чињеницу да је у већем броју раније објављених истраживања, утврђено да ефикасност усвајања садржаја наставног предмета Специјално физичко образовање, у значајној мјери зависи од моторичких способности студената, резултати овог истраживања могли би да буду корисна информација у даљој едукацији студената код планирања и програмирања наставних садржаја из наставног предмета Специјално физичко образовање. 


\section{ЛИТЕРАТУРА}

Амановић, Ђ., Јовановић,С., Мудрић, Р. (1999). Утицај програма Специјалног физичког образовања на базичне моторичке способности полицајаца приправника. Безбједност 41(6), 778-793.

Амановић, Ђ., Мудрић, Р., Јовановић, С. (2002). Развој различитих видова силе под утицајем програма Специјалног физичког образовања код студената Више школе унутрашњих послова. У: Зборник радова наставника ВШУП 6 (53-70). Земун: ВШУП.

Амановић, Ђ., Милошевић, М., Мудрић, Р. (2004). Методе и средства за процјену, праћење и развој мишићне силе у Специјалном физичком образовању. Београд: Инпресс.

Арлов, Д. (1999). Ефекти третмана Специјалног физичког образовања на базично - моторичке и специфично моторичке способности студената. Необјављена докторска дисертација. Нови Сад: Факултет физичког васпитања Универзитета у Новом Саду.

Благојевић, М., ћирковић, З., Милошевић, М., Стојчић, Р., Јовановић, С., Арлов, Д., и Допсај, М. (1994). Утицај неких адаптационих карактеристика приправника милиционара на ефекте учења моторичких алгоритама и програма у Специјалном физичком образовању. У: Зборник радова првог савјетовања из Специјалног физичког образовања Полицијске академије у Београду (49-56). Београд: Полицијска академија.

Благојевић, М. (1996). Утицај морфолошких и моторичких карактеристика полицајаца на ефикасност учења џудо техника. Београд: Полицијска академија.

Благојевић, М. (1997). Утицај одређених моторичких третмана Специјалног физичког образовања на промјену морфолошких и моторичких карактеристика студената Полицијске академије. Необјављена докторска дисертација. Београд: Факултет физичке културе.

Благојевић, М. (2002). Утицај наставе Специјалног физичког образовања на промјене морфолошких и моторичких карактеристика студената Полицијске академије. Београд: Министарство за НИТ Републике Србије.

Божић, С., Милошевић, М., Зулић, М. (1990). Утицај неких антрополошких карактеристика радника на структурирање моторичких алгоритама у Специјалном физичком образовању. Специјално физичко образовање, 2, $128-135$.

Гужвица, М. (2005). Повезаност неких координационих способности са нивоом усвојености техника из програма специјалног физичког образовања. Безбједност, полиција, грађани, 2, 353-361.

Гужвица, М. (2006). Валоризација новог модела ситуационо - моторичке обуке студената Високе школе унутрашњих послова. Необјављена докторска 
дисертација. Београд: Факултет спорта и физичког васпитања Универзитета у Београду.

Гужвица, М. (2007). Предикција утицаја латентних моторичких способности и морфолошких карактеристика на успјешност извођења техника из програма специјалног физичког образовања. Безбједност, полиција, грађани, 1, 879-890.

Гужвица, М. (2008). Латенте моторичке структуре значајне за извођење удараца челом песнице Безбједност, полиција, грађани, 1, 21-30.

Dopsaj, M., Milošević, M., Arlov, D., Blagojević, M., Stefanović, Đ. (1996). The structure of changes in mehanic contractile characteristic of leg extensor muscles caused by combined strenght training during one-year motor learning program in Special physical education. In: Proceeding of International Congress on Sport Psychology (pp.313-318). Komotini, Greece.

Dopsaj, M., Milošević, M., Blagojević, M., \& Mudrić, R. (2002). A new approach to discriminating athletes according to their specific fitness status when considering isometric force characteristics. In: Hakkkinen K., Tihanyi J. (ed.) 3rd International conference on strength training, - Abstract book. (pp. 7778). Budapest: Semmelweis University Faculty of Physical Education and Sport Sciences.

Јанковић, Р., Коропановски, Н., Вучковић, Г., Димитријевић, Р., Атанасов, Д., Миљуш, Д., Маринковић, Б., Ивановић, Ј., Благојевић, М. и Допсај, М. (2008). Тренд промене основних антропометријских карактеристика студената Криминалистичко-полицијске академије у току студија. Наука, безбедност, полиција 13 (2), 137-152.

Јанковић, Р., Вучковић, Г., Благојевић, М. (2014). Утврђивање норматива за процену специфичне спретности полицајаца за студенте Криминалистичкополицијске академије. Безбедност, 56 (2), 65-76.

Копаш, Ј. (1994).Утицај часова специјалног физичког образовања на базични моторички статус полазника курса за милиционаре приправнике на Клиси. У: Зборник радова првог савјетовања из Специјалног физичког образовања Полицијске академије у Београду (147 -153). Београд: Полицијска академија.

Милошевић, М. (1985). Одређивање структуре моторичких својстава милиционара. Земун: Виша школа унутрашњих послова.

Милошевић, М., Јовановић, С., Стојичић, Р., Арлов, Д., Благојевић, М., Допсај, М. (1994). Модел едукације у специјалном физичком образовању. У: Зборник радова првог савјетовања из Специјалног физичког образовања Полицијске академије у Београду (стр.9-22). Београд: Полицијска академија.

Милошевић, М., Мудрић, Р., Амановић, Ђ. (2003): Методе и средства за развој мишићне силе у спорту. У: Зборник радова са 3. научно стручног симпозијума. Наука и карате спорт. (стр. 83-88). Нови Сад: Карате савез Војводине.

Мудрић, Р., Јовановић, С., Милошевић, М., и ћирковић, 3. (1994). Предлог батерије тестова за процену сложених структура карате техника у 
фази усмерене обуке у СФО-у. У: Зборник радова првог савјетовања из Специјалног физичког образовања Полицијске академије у Београду (124133). Београд: Полицијска академија.

Мудрић, Р., Божић, С., Суботички, С., и Балтић, Р. (1998). Резултати праћења базичних моторичких способности студената ВШУП-а у Земуну. У: Зборник радова наставника ВШУП (219-225). Београд: Виша школа унутрашњих послова.

Паспаљ, Д. (2008). Утицај базичних моторичких способности на ефикасност извођења техника бацања из програма Специјалног физичког образовања. Необјављен магистарски рад. Бања Лука: Факултет физичког васпитања и спорта Универзитета у Бањој Луци.

Паспаљ, Д. (2009). Латентне моторичке структуре значајне за извођење технике чишћења наступајуће ноге из програма Специјалног физичког образовања. Безбједност, Полиција, Грађани 1, 173-186.

Паспаљ, Д. (2010). Ефекти различитих континуитета наставе на ниво усвојености техника падова, чишћења и бацања из програма специјалног физичког образовања. Безбједност, полиција, грађани 3-4, 513-522.

Паспаљ, Д. (2012). Разлике у неким моторичким способностима студената Високе школе унутрашњих послова с обзиром на ефикасност извођења одбране од напада штапом одозго. Безбједност, полиција, грађани, 3-4, 467-478.

Паспаљ, Д. (2013). Полни диморфизам антрополошког профила студената Високе школе унутрашњих послова у функцији рјешавања проблемских ситуација из Специјалног физичког образовања. Безбједност, полиција, грађани, 3-4, 167-180.

Родић, Н. (1994). Утицај програма физичке обуке војника на њихове физичке способности. У: Зборник радова првог савјетовања из Специјалног физичког образовања Полицијске академије у Београду (115-123). Београд: Полицијска академија.

Стојчић, Р. (1994). Одређивање моторичке ефикасности припадника специјалних јединица. Необјављен магистарски рад. Београд: Факултет физичке културе, Универзитета у Београду.

Суботички, С. (2003). Повезаност морфолошких и моторичких карактеристика студената ВШУП са ефикасношћу реализације техника каратеа из програма Специјалног физичког образовања. Необјављен магистарски рад. Нови Сад: Факултет физичке културе Универзитета у Новом Саду. 